\title{
Interaction and Reciprocity of Space Law and Human Rights
}

\author{
Vishwas Puttaswamy ${ }^{1 *}$, Dr. Ramesh ${ }^{2}$ \\ ${ }^{1}$ Assistant Professor, SBRR Mahajana Law College, Jayalakshmipuram Mysore, Karnataka, India \\ ${ }^{2}$ Professor, Department of Studies in Law, University of Mysore, Manasagangotri, Mysore, Karnataka, India
}

DOI: $10.36348 /$ SJHSS.2019.v04i10.008

| Received: 15.10 .2019 | Accepted: 25.10.2019 | Published: 30.10.2019

*Corresponding author: Vishwas Puttaswamy

\section{Abstract}

Space is a metaphor for the future. Outer space is not just void beyond earth's atmosphere, but an arena for ceaseless human evolution. When through human industry a small round metal object was shot into space for the first time, a rare opportunity to carry human rights into outer space emerged. Since the inception of the outer space treaty, the relationship between outer space exploration and human rights is grounded on the doctrine of exploration for the philosophical or spiritual benefit of mankind. The technological and scientific advancement of the twenty-first century especially in aerospace engineering and space exploration popularly known as 'space-age' along with access and control of information known as 'information age' is arguably the defining characteristics of the current era of human civilization. In regard to outer space exploration and exploitation, a very important problem is represented by the conflict between the right of state with respect to sovereignty and the rights of individual in regard to development. Since the appearance of 'province of mankind' and 'benefit of mankind' provisions in the outer space treaties and agreements, controversy regarding the intent and meaning of the terms in regard to nation's right to explore and use common environment for not just one's own benefit but to share benefits derived with the rest of the world has escalated. The availability of freedom of information regardless of frontiers, an integral part of freedom of expression to seek, receive and impart information and ideas as a fundamental consideration among states in space is explored. The impact of right to development in space exploration whether it is a dead-end or does it open new avenues of thinking and possibility of better implementation of human rights in space law from benefit of mankind perspective is examined. The paper explores the conflict and complementary relationship between the two bodies of law and argues that human rights could only find it's place in space law in a dialectic process with state rights. Space law's domination by concept of state's sovereignty over concept of humanity, the dialectic process can offer hint for the method to be used to determine the nature of the relationship between the two. The first part of this research paper examines the relationship between space exploration and human rights by invoking various provisions of both bodies of law regarding benefit of mankind principles and what it means to define outer space as province of all mankind. The second part seeks to understand the interaction between space law and first generation of human rights and the journey of some of the important Resolutions that gave rights beyond frontiers. The third part determines that right to development can provide a roadmap for transformational change that can elegantly find solution to reconcile the conflict between the state's right and individual freedom. The dialectical approach finds that the way to balance needs of developing countries and the obligations of developed countries in outer space activities can be found by invoking right to development concept. The paper concludes with findings that in pursuit of development, non- discrimination and mutual benefit principles, the interaction and reciprocity of space law and human rights does afford an opportunity to better implement human rights in outer space.

Keywords: Interaction and Reciprocity, province of mankind, outer space.

Copyright @ 2019: This is an open-access article distributed under the terms of the Creative Commons Attribution license which permits unrestricted use, distribution, and reproduction in any medium for non-commercial use (NonCommercial, or CC-BY-NC) provided the original author and source are credited.

\section{INTRODUCTION}

The reason why we bother about space is: to learn, to marvel and to profit - three deeply human desires. And fittingly, the opening of space to exploration and use has profound effects on humanity.

The basic requirement of humanity is cherished in various human rights instruments. Human rights are understood as entitlements for each individual or collective to live a life of dignity regardless of age, sexuality, race, nationality, religion, ethnicity or values that keep society fair, just and equal. These rights are laid down in many agreements and covenants etc, recognised internationally. Just like human rights are indivisible and universal, the Outer Space laws, from Outer Space Treaty, 1967 [1] to Moon Agreement, 1984 
[2], too focuses on international cooperation and peaceful use of outer space for the benefit of all countries and people, in short benefit of mankind.

Human Rights are recognised around the globe from ancient times, may it be in Confucian teachings, Hindu religion, Buddhist tradition, Hammurabi Code, the Roman law and Greek Stoics notion of jus gentium, Magna Carta or the English Bill of Rights. While all these notions and agreements have generally been identified as earth oriented, there is no fundamental reason for not recognising their applicability to the space environment.

Article 1 [3] of the Universal Declaration of Human Rights provides that Human rights are intimately related to the notion of human dignity; captures the very essence of human rights instruments in respect to human dignity and human freedom. The argument that space exploration contributes to human life on earth as a result of exploration, invention, experiments and technology spin-offs from spacerelated activities, ultimately promote human dignity is indubitable.

The outer space is open to all as "province of mankind" and the activities in outer space is carried on in accordance with the Outer Space Treaty (OST) of 1967, considered as the bedrock and foundation of outer space legal regime along with other four associated legal instruments, international law, UN Charter and respective national space legislation, for peaceful, as in non- aggressive and beneficial use of outer space. The space law unreservedly insists on nonappropriation of space and planets by states and the Astronauts are regarded as "envoys of mankind in outer space". In the interest of maintaining international peace and promoting international cooperation, outer space is mooted as "common heritage of mankind". The wide usage of these phrases to attribute outer space has evolved itself into a doctrine of customary law that mankind is a legal beneficiary of the exploration and exploitation of space.

Paragraph 1 of Article I of Outer Space Treaty, 1967 [4] prescribes that the exploration and use of outer space must be carried out 'for the benefit of mankind and in the interest of all countries, irrespective of their degree of economic or scientific development, and shall be the province of all mankind'. The word mankind was first conceptualised during the negotiations surrounding the formulation of the outer space treaty of 1967 [5]. Since then, in the international law realm, phrases like "for the benefit of mankind", "common heritage of mankind" [6], "province of mankind" [7], "envoys of mankind" have come into wide usage.

Jus humanitatis is "common law of humanity" [8], a departure from traditional international law, and predominantly governs international relations among states, the law governing all humanity. Human rights as jus humanitatis can be viewed as the law of the human race, and be identified as the fourth dimension of political reality. Outer Space explorations and treaty since its inception have addressed not only states or nations or international community but people and mankind at large have been its ultimate beneficiary and therefore space treaty has been a positive contributor to the identification of that fourth dimension.

The "common heritage of mankind" and the "province of mankind" are distinct legal concepts in international law, developed in the last quarter of the last century. Since the initial appearance of these provisions in the space law, it has stirred controversy and being constantly.

Attacked by lawyers, politicians and businesspeople. The controversy that escalated mostly between space-faring states and non-faring states in the late 1970s was regarding the intent and meaning of the terms in regard to nation's right to explore and use common environment for not just own's benefit but to share benefits derived with the rest of the world.

The present interpretation now stands to mean, mankind and humanity provisions are tools available for the advancement of global interest, and commercial interest of states needs to be compatible with the common good or interest of mankind.

A desultory glimpse at the history of the word "mankind" in international law can be traced to the negotiations from outer space treaty by the United States of America and USSR to the Moon Treaty. The USA generally interpreted "common heritage of mankind" and "the province of all mankind" to be indistinguishable and therefore both are simply an extension of res communis principle in international law [9]. However, the USSR initially rejected the "common heritage of mankind" concept for is roots in bourgeois Roman law [10], and later it came to acknowledge both concepts as separate and different [11] and accepted both in the lines of Charter of United Nation, to mean all nations had vested rights in common resources and should be shared equitably among them [12]. The Least Developed Countries (LDCs) however, collectively developed an opinion that since most of this concept was conceptualised prior to their attaining nationhood, they refused to be bound by it [13], and later during the Law of the Sea negotiations LDCs collectively sailed from rejecting the "province of mankind" notion towards accepting "common heritage of mankind" principle, that was later incorporated into the Moon Treaty [14] and Law of the Sea Convention.

\section{Relationship between Space Law and Human Rights}

The mankind provisions which emerged from the communal mind had its first thrust beyond earth when through human industry a small round metal object 
was shot into space into a stable orbit above the earth [15]. The international law principles regarding use and exploitation of outer space and celestial bodies, since Sputnik, has remained applicable in space. Article III of the Space Treaty is clear about the applicability of international law and the UN Charter in Outer Space.

\section{Article III is as follows}

"States Parties to the Treaty shall carry on activities in the exploration and use of outer space, including the moon and other celestial bodies, in accordance with international law, including the Charter of the United Nations, in the interest of maintaining international peace and security and promoting international co-operation and understanding [16]."

Article III's reference to UN Charter and international law naturally consider and include human rights provisions. Moreover, the 1982 Principles on Direct TV Broadcasting [17] under Article 4 explicitly refers to the applicability of international law [18] and UN Charter. Article 1 of the Outer Space Treaty, begins with the declaration that any and all exploration and use of outer space shall be carried out for the benefit of all counties regardless of their economic and technological development and such activity shall ultimately secure the benefit of mankind.

Article 4 [19] and Article 11 [20] of the Moon Agreement spells out that the lunar environment including the moon and its resources shall be considered as the common heritage of mankind and the exploration and use of moon shall be done as the province of mankind respectively. The Rescue Agreement [21, 22] also provides assurances that nations around the world would in the event of a distress signal or issue, help to rescue and return astronauts and space objects to their home nation, and the contracting parties are to oblige and sign this agreement prompted by sentiments of humanity [23].

Finally, but importantly, all space agreements can be argued, are structured around one common goal, the benefit of mankind, protection of international peace and secure international cooperation and security. Such agenda similar to the Article IV of the OST and Article III of the Moon Agreement, that contains arms control provisions, can be said univocally regulate use and exploration of outer space for peaceful purposes, ascribe to the most important human right.

Space law makes provisions for human rights as interest in development, manifesting treaties and agreements for social and cultural development. Article I of the Outer Space Treaty explicitly proclaims that the exploration and use of outer space "shall be carried out for the benefit and interests of all countries, irrespective of their degree of economic or scientific development".
One can also find this interest in development in the Moon Agreement in Article IV.

\section{Article VI. 1 of the Moon Agreement states that}

"There shall be freedom of scientific investigation on the moon by all States Parties without discrimination of any kind, on the basis of equality and in accordance with international law [24]."

Principle II of the Principles on Remote Sensing [25] clearly states that "remote sensing activities shall be carried out for the benefit and in the interests of all countries, irrespective of their degree of economic, social or scientific and technological development, and taking into particular consideration the needs of the developing countries [26]." Confirms the necessities of development in all its aspects. Principle XI of Principles on Remote Sensing also states that such remote sensing shall provide the protection of mankind from disasters.

One of the prime benefits of outer space activities is the exchange of information with communication and broadcasting satellites. The human rights law provides to all, the right to access information held by public bodies. Article 19 [27] of the Universal Declaration of Human Rights states that the fundamental right of freedom of expression encompasses the freedom "to seek, receive and impart information and ideas through any media and regardless of frontiers [28]." Space law inordinately touches upon the freedom of information. Article 2 of the Principles Governing the Use by States of Artificial Satellites for International Broadcasting [29] the broadcasting, transmission and simulcasting by artificial satellites should promote mutual exchange of information.

\section{Article 2 is as follows}

"Such activities should promote the free dissemination and mutual exchange of information and knowledge in cultural and scientific fields, assist in educational, social and economic development, particularly in the developing countries, enhance the qualities of life of all peoples and provide recreation with due respect to the political and cultural integrity of States."

In perusal, the principal theme running through the international law for the space environment mainly focuses on the province of mankind and benefit of humanity, and mutual connection of space law and human rights regarding international peace and security and the broadest possible respect for human dignity, thus the relationship between space law and human rights can be clearly evinced.

Human rights without a doubt have found its way into space law debates including "common heritage of mankind", rendering assistance to "envoys of mankind", the next step is to determine the nature of 
interaction and reciprocity. The two distinct bodies of law space law and human rights law, are they complementary or contrasting to each other needs a reflection.

In the pursuit to dissect the nature of both fields of law, it is pertinent to analyse and highlight first, some defining characteristics of these two legal bodies.

The legal realm of space law governs, hegemonically perhaps, notions of peaceful use of outer space, of non-aggressive exploration of outer space, promotion of international cooperation and security, along with the core idea of state's sovereignty and liability in outer space. The notions of humanity, of mankind, of common heritage, of development no doubt are addressed and part of space law, the rights of states veritably still dominate them. The human rights, therefore, could only find it's a place in space law in a dialectic process with state rights. This process perhaps determines whether each is complementary or confrontational to one another.

The notions of the "Right of Man" and other such concepts of the human right are as old as humanity. In 1979, Karel Vasak, a Czech jurist classified human rights into three categories, at the International Institute of Human Rights in Strasbourg. Karel based his theory on the three tenants of the French Revolution: Liberty, Equality and Fraternity [30], and called these human rights norms as civilpolitical, socio-economic, and collective-developmental rights [31]. Louis B Sohn, an Austrian-American jurist, revered as the grandfather of international Human Rights law in the United States [32], classified human rights into three generations. The various rights contained in the Covenant of Civil and Political Rights come under the first-generation category. The secondgeneration rights refer to economic and social rights, considered originated in the Russian Revolution of 1917. The Third-Generation rights also called Collective Rights, Louis B Sohn argued that individuals are also members of such units, groups or communities as a family, professional members, racial group, nation and state. The third generation of human rights includes right to self-determination, right to development, right to peace etc.

Space law, in that sense, has special links with the first and third-generation human rights. The right to freedom of information and right to development can be associated with direct television broadcasting and remote sensing activities in outer space. The thirdgeneration human rights, especially the right to development is of special interest here, as this influences directly the present and future of space activity and space law.
Right to Seek, Receive and Impart Information

In the $13^{\text {th }}$ century, Magna Carta a part of British tradition and mandate, and the French Declaration of 1789 hypostatized the first generation of human rights. The various rights contained in the International Covenant on the Civil and Political Rights of 1966 [33] come under this category.

The interaction between space law and the first generation of human rights appeared during the discussion on direct television broadcasting [34]. For the first time, debate on freedom of information in Article 19 [35, 36] of the International Covenant on Civil and Political Rights, 1966 was extended to include space activities and space law as a confrontation to the principle of prior consent. The prior consent principle in space law and international law is significant as it symbolises state sovereignty.

Freedom of information, an integral part of the fundamental right of freedom of expression, is recognized by the Resolution 59 of the UN General Assembly adopted in 1946. The free flow of information as a fundamental consideration among states in space activities was therefore in vogue much earlier. Many discussions and deliberations were underway with regard to freedom of information since the adoption of UNESCO's “Declaration of Guiding Principles on the Use of Satellites Broadcasting for Free Flow of Information, the Spread of Education and Greater Cultural Exchange [37].’

USSR, the Eastern Bloc and the third world countries in perusal to the UNESCO's freedom of information, proposed Resolution 39/92 on the "Principles Governing the Use by States of Artificial Earth Satellites for International Direct Television Broadcasting" 1982 which was adopted a decade later of the 1972 Declaration [38] to recognize not only the applicability of international law, particularly the human rights instruments [39] in space activities, but also provisions regarding obligation of States with respect to prior consultation and State's consent [40]. However, it was rejected by most of the other States capable of having a direct television system [41].

The dissension between the United States and the Soviet Union resulted in conflict between space law and the first-generation human rights. This discordance can be argued to be the reason for the 1982 Resolution's inability to translate into a rule of positive law [42]. During the period between 1972 and 1982, any progress regard to direct TV broadcasting was marred by the said conflict. The failure of the customary norm to transform prior consent into an obligatory rule of international law was seen as an inevitable consequence since the concept of sovereignty as opposed to human rights [43]. 
On $22^{\text {nd }}$ May 1990, the ambiguous and confrontational conflict between space law and the first generation of human rights came for consideration publicly in Autronic A G v. Switzerland [44] regarding broadcasting rights and the right of a person to receive information. The European Court of Human Rights delivered judgment in Strasbourg and opined that the lack of the broadcasting state's consent infringed company's right to receive information.

Autronic AG, a Swiss company specialised in home electronics, particularly dish antennas. In 1982, it requested the Swiss government to allow it to show a public Soviet television programme at an exhibition in Zurich. The Autronic company received this Soviet programme directly from a Soviet telecommunication satellite G-Horizont by means of its parabolic antennas without the prior consent of the Soviet government.

The Swiss government refused permission, basing its decision on Article 22 [45] of the 1973 International Telecommunication Convention and Article 23 [46] "Broadcasting Services" of the ITU Regulation on Radiocommunication. The Autronic approached the Strasbourg Commission and pleaded that denial of permission by the Swiss government was in violation of Article 10 of the European Convention of Human Rights. Article 10 of the ECHR deals with Freedom of Information.

\section{Article 10.1 Reads As Follows}

"Everyone has the right to freedom of expression. This right shall include freedom to hold opinions and to receive and impart information and ideas without interference by public.

Article 22 (2) - Nevertheless, they reserve the right to communicate such correspondence to the copetent authorities in order to ensure the application of their internal laws or the execution of international conventions to which they are parties.

Authority and regardless of frontiers. This Article shall not prevent States from requiring the licensing of broadcasting, television or cinema enterprises [47]."

The European Court of Human Rights found that Article 10 of the Convention was violated, delivered judgement in Strasbourg [48] that this denial of permission by the Swiss government was an unjustified interference. In paragraph 63 of the judgement, the court holding that interference was not "necessary in a democratic society," observed that even in the interest of defending public order by regulating radiocommunications, the Swiss government cannot introduce laws and regulations in general and blanket prohibition of all parabolic antennas. The Court concluded that "a refusal based on the lack of the broadcasting State's consent has infringed the company's freedom to receive information and ideas regardless of frontiers [49].”

Prior to Switzerland and USSR defending the principle of prior consent on one hand and other states, in this case, private business defending right to freedom of information without obstruction from public authorities on the other, debate regarding conflict between principle of sovereignty and freedom of information has been going on in the United Nations prior to the Autronic case. But, this case, not only illustrated the existence of the conflict between space law and human rights but also settled the matter by taking broader benefit of mankind approach.

State sovereignty and human rights have been highly contested concepts, pitting national sovereignty against human rights is a false contradiction and it is counterproductive. Nation- states exploit the tensions between state sovereignty and human rights by claiming the inviolability of the one when it is beneficial for them to violate the other [50]. Thus, a look at the relation between space law and human rights needs a different perspective.

\section{Right to Development}

Seventy years ago, when the world was facing its challenges post World War II, the idea of development was equated with economic growth. In 1986, when the United Nations General Assembly adopted "Declaration on Right to Development" [51], development was defined to mean economic, social, cultural and political progress aimed at the constant improvement and well-being of the entire population.

Right to development calls for active, free and meaningful participation in development and fair distribution of its benefits by all states, developed and developing alike. It entrusted states with a duty to direct development for the well-being of all people and called on them to work together.

The Declaration is a roadmap for transformational change and requires states to ensure that they are responsible for their actions and their impact at home and abroad. Therefore, right to development, a third-generation human right has more latitude to analyse the impact of space exploration, than the interaction between space law ie., broadcasting rights and first-generation human rights namely freedom of information, that appears to be a narrow rationale opposing one another, driving the entire argument to a stalemate. The approach to understanding this interaction between the two bodies of law as conflict drives us inevitably to a dead end. Just like in the Autronic case, either sovereignty has to retreat in front of human rights or human right has to withdraw in front of sovereignty.

The second generation of human right namely right to education which can also be evaluated against 
space law would also reach a similar dead-end outcome. But some respite can be sought by bringing in the social and cultural rights dimension of third-generation human rights to this debate. Here the failure of the 1982 Resolution $37 / 92$ needs a recall of its inability to translate into a rule of positive law because the interaction of two bodies of law was seen as a conflict. In order to avoid such a problem, an elegant solution to reconcile the two would require seeing the interaction of two bodies of law not as conflict but as complementary to one another.

The third-generation human rights mainly deal with collective developmental rights is also referred to as solidarity rights of people and group. The emphasis is on sustainable development and rights of future generations. Israel JJ, in the United Nation Report on the Right to Development, 1983 characterized the third generation of human rights as synthetic in nature [52] and its composite nature sometimes ends up in unsatisfactory results. The synthetic character of the third-generation human rights was also exposed in the United Nation debates preceding the adoption of the Right to Development [53].

However, the right to development, particularly its social and cultural dimensions appeared in two space law agreements; the International TV Broadcasting Principles and the Remote Sensing Principles, is not as useless and redundant it was believed it to be. This is because the composite nature of the human right, which has a double dimension containing both individual and collective rights including the right of states facilitates conciliation between space law and human rights.

International direct broadcasting satellites have significant international political, economic, social and cultural implications. The "Principles Governing the Use by States of Artificial Earth Satellites for International Direct Television Broadcasting [54]" in its objectives mentions everyone's right to seek, receive and impart information within the confines of sovereign rights of the state including non-intervention. These provisions strike a balance between the defence of state sovereignty and the need for development.

In developing countries, the biggest factor to facilitate direct TV broadcasting is to assist in educational, social and economic development [55], therefore access to technology must be available to all states without discrimination [56]. The provisions of non-discrimination, of non- intervention, of compatibility with sovereign rights of the state, of right to information benefit not only space-faring states but also non-space faring particularly developing countries.

The undermentioned paragraph on International Cooperation specifically addresses special consideration for developing countries.

\section{Paragraph D-6 Reads as Follows}

"Activities in the field of international direct television broadcasting by satellite should be based upon and encourage international co-operation. Such co-operation should be the subject

Access to the technology in this field should be available to all States without discrimination on terms mutually agreed by all concerned of appropriate arrangements. Special consideration should be given to the needs of the developing countries in the use of international direct television broadcasting by satellite for the purpose of accelerating their national development [57]."

In reality, the above broad principles of the benefit of humanity were lost in translation and failed to be accepted or respected by the broadcasting states, as two hurdles, prior consent requirement and broad obligation on developed states led to its failure. A legal vacuum was thus created in the Principles on Direct Television Broadcasting.

In the negotiations on Principles on Remote Sensing, the developing countries claimed sensed State's prior consent for distribution of data collected by remote sensing states too created a legal hurdle, however, a possible dead-end was avoided when in 1982, Brazil, a developing country renounced its claim and this over a period of time led eventually to progressively abandon prior consent requirement [58].

By doing away with prior consent criteria, necessities of development in all aspect and mutual cooperation were ensured by imposing a specific obligation on sensing state to notify secretary- general of the United Nations with relevant information.

\section{Principle IX reads as follows}

"In accordance with article IV of the Convention on Registration of Objects Launched into Outer Space and article XI of the Treaty on Principles Governing the Activities of States in the Exploration and Use of Outer Space, including the Moon and Other Celestial Bodies, a State carrying out a programme of remote sensing shall inform the Secretary-General of the United Nations. It shall, moreover, make available any other relevant information to the greatest extent feasible and practicable to any other State, particularly any developing country that is affected by the programme, at its request."

In remote sensing activity, there are two kinds of information- one that is raw data and the other that is analysed. Principle XII mandates that the sensed state must have access to the latter, and this principle takes into account the interest of the developing countries. To promote international cooperation and fulfil needs of a developing country, Principle XIII gives developing 
countries the opportunity to participate in remote sensing activities for mutual benefit.

The Principles Relating to Remote Sensing, on the one hand, led sensing states to abandon attachment to sovereignty and on the other hand by developing countries to abandon prior consent restriction strikes balance between the two bodies of law, can be said is based on compromise.

The right to development, a third-generation human right, therefore, offers protection in a positive way. The compromise between remote sensing state and the sensed state facilitates economic independence, political integrity and genuine respect for each other's sovereignty based on reciprocity.

\section{CONCLUSION}

Humans are getting addicted to outer-space exploration and its benefits. The exploration of space inherently has become a necessity and not a choice, which affects all of humanity. The authors of space law clearly perceived space technology and exploration in the service of mankind. Space programmes are not only significant for the nations' economy or homeland security and technology superiority today, but is interpreted as indispensable for the ordinary citizens whose lives are being augmented by its enormous positive potential.

The synthetic character of Article I (2) [59] of Covenant of Civil and Political Rights and Article I (2) [60] of Covenant of Economic, Social and Cultural rights covenants of 1966 [61] gives man the right to freely dispose his natural wealth in pursuit of development and such right available without discrimination respectively for mutual benefit, can provide necessary tools to avoid an enmesh of state sovereignty versus human right debate.

However, in today's space-age and future's interplanetary age or possible Skynet age, where artificial intelligence reaches space, a mere avoidance of tangle between state sovereignty and the right to development debate is not enough, but a concrete and practical approach to making the right to development or another kind of human right operational in outer space.

A concession or a new rationale that can identify and permit rights of the future generation, that belong to humans as a whole and treat common assets of the whole humanity as rights of man would aid to avoid sovereignty versus the right to development dissonance for the true benefit of mankind.

The philosophy of 'benefit of mankind' in space laws would mean to include future generations of human beings having the same natural rights as the present generation. Man's footprints in outer space so far will and tomorrow will have effect and consequence on the welfare of future generations and those who do not have a voice. To provide the right to the future generation who are yet to come into existence, firstly need to understand that future generation whose right is not recognized today, definitely have interests, which means the present generation is under a moral obligation to consider.

Taking into account further progress in space law in the future, the needs of developing countries, future developed countries and future generations, human rights can only be better implemented if a concrete proposal is discussed away from sovereignty by space-faring and- space faring, by developed and developing countries together. However, rather than arguing in terms of right to development perspective that can only avoid the conflict by compromise, a new kind of exhaustive and all-encompassing 'the rights of future generation' a fourth generation of human rights regulatory framework that can cope with challenges of long-term responsibility and facilitate sustainable use and development of space could fit the bill. The future use and exploration of outer space, for this reason, should be considered from a new generation of human rights perspective through both 'hard' and 'soft' law instruments to allow all states, people and all of humanity, present and future reach their full potential.

\section{REFERENCES}

1. The Treaty on Principles Governing the Activities of States in the Exploration and Use of Outer Space, including the Moon and other Celestial Bodies, of 27 January 1967.

2. 34/68. Agreement Governing the Activities of States on the Moon and Other Celestial Bodies New York, 5 December 1979

3. Article 1, UN General Assembly, Universal Declaration of Human Rights, 10 December 1948, 217 A (III), available at: https://www.refworld.org/docid/3ae6b3712c.html [accessed 14 July 2019, Time 00:21]

4. 2222 (XXI). Treaty on Principles Governing the Activities of States in the Exploration and Use of Outer Space, including the Moon and Other Celestial Bodies.

5. Bueckling Adrian, The Strategy of Semantics and the "Mankind Provisions" of the Space Treaty. 7 J. Space L., 15-22 (1979); Stephen Gorove, Limitations on the Principle of Freedom of Exploration and Use in the Outer Space Treaty:Benefit and Interests, in PROCEEDINGS OF THE THIRTEENTH COLLOQUIM ON THE LAW OF OUTER SPACE (1970).

6. The text of Article XI (1) is as follows: The moon and its natural resources are the common heritage of mankind, which finds its expression in the provisions of this Agreement, in particular in paragraph 5 of this article.

7. The text of Article 1 of Outer Space Treaty 1967 is as follows: The exploration and use of outer 
space, including the moon and other celestial bodies, shall be carried out for the benefit and in the interests of all countries, irrespective of their degree of economic or scientific development, and shall be the province of all mankind.

8. Oxford

Reference, https://www.oxfordreference.com/view/10.1093/a cref/9780195369380.001.0001/acref-

9780195369380- e-1111 [accessed 14 July 2019, Time 01:00]

9. Robinson G.S. and White H. M. Jr. (1986) Envoys of Mankind - A Declaration of First Principles for the Governance of Space Society, p. 187. Smithsonian Institution, Washington DC

10. Dekanozov R. V. (1979) Juridicial nature of Outer Space, including the Mon and other Celestial bodies. Proceedings of the Seventeenth Colloquium on the Law of Outer Space, pp. 200201. AIAA, New York.

11. Maiorsky B (1986) A few reflections on the meaning and the interrelation of "provine of all mankind" and "common heritage of mankind" notions. Proceedings of the Twenty-Ninth Colloquium on the Law of Outer Space. pp. 58-59. AIAA. New York.

12. Robbionson G.S. and White, 1986, p.188 Supra

13. Ibid p.181

14. Article 11, Moon Agreement 1979 Supra

15. Cadbury, Deborah. Space race: the epic battle between America and the Soviet Union for dominion of space. New York, HarperCollins, 2006. Pp. 370 First published in Great Britain in 2005 by Fourth Estate. TL789.8.U5C33 2006.

16. 2222 (XXI). Treaty on Principles Governing the Activities of States in the Exploration and Use of Outer Space, including the Moon and Other Celestial Bodies

17. A/RES/37/92, December 10, 1982

18. Applicability of International Law - Activities in the field of international direct television broadcasting by satellite should be conducted in accordance with international law, including the Charter of the United Nations, the Treaty on Principles Governing the Activities of States in the Exploration and Use of Outer Space, including the Moon and Other Celestial Bodies, of 27 January 1967, the relevant provisions of the International Telecommunication Convention and its Radio Regulations and of international instruments relating to friendly relations and co-operation among States and to human rights.

19. The text of Articcle IV (1) is as follows: The exploration and use of the moon shall be the province of all mankind and shall be carried out for the benefit and in the interests of all countries, irrespective of their degree of economic or scientific development. Due regard shall be paid to the interests of present and future generations as well as to the need to promote higher standards of living and conditions of economic and social progress and development in accordance with the Charter of the United Nations.

20. Op cit

21. 2345 (XXII). Agreement on the Rescue of Astronauts, the Return of Astronauts and the Return of Objects Launched into Outer Space

22. In accordance with a decision taken by the General Assembly at its 1640th plenary meeting, on 19 December 1967, the question dealt with in the addendum to the report of the Committee on the Peaceful Uses of Outer Space was examined directly in plenary meeting, and the present resolution was adopted without reference to the First Committee.

23. The text of the Article 4 is as follows: If, owing to accident, distress, emergency or unintended landing, the personnel of a spacecraft land in territory under the jurisdiction of a Contracting Party or have been found on the high seas or in any other place not under the jurisdiction of any State, they shall be safely and promptly returned to representatives of the launching authority.

24. Op cit Resolution 34/68

25. A/RES/41/65, December 3, 1986

26. Supra

27. Universal Declaration of Human Rights. https://www.un.org/en/universal-declarationhuman-rights/

28. "Freedom of Information", Communication and Information,

http://www.unesco.org/news/en/communicationand- information/freedom-of-expression/freedomof-information/ [Accessed 14 July 2019, Time 14.37]

29. A/RES/37/92, December 10, 1982

30. Karel Vasak, "Human Rights: A Thirty-Year Struggle: The Sustained Efforts to give Force of law to the Universal Declaration of Human Rights", UNESCO Courier 30:11, Paris: United Nations Educational, Scientific, and Cultural Organization, November 1977.

31. Ibid

32. Pasqualucci, Jo M. "Louis Sohn: Grandfather of International Human Rights Law in the United States." Human Rights Quarterly, vol. 20, no. 4, 1998, pp. 924-944. JSTOR, www.jstor.org/stable/762794. [accessed 14 July 2019, Time 18:20]

33. International Covenant on Civil and Political Rights, Adopted and opened for signature, ratification and accession by General Assembly resolution 2200A (XXI) of 16 December 1966 entry into force 23 March 1976, in accordance with Article 49

34. Colliard Cl. A.; AFDI, 1972. Pp. 717-730; Colliard Cl.A; "La television directe par satellites", in La circulation des information et le droit international, Colloque de Strasbourg, Paris, Pedone, 1978, pp. 143-170. Cherreau B. : "La television directe" in Driot de'l Espace, Paris, 
Pedone, 1989, pp. 255-278.

35. Article 19.2 "2. Everyone shall have the right to freedom of expression; this right shall include freedom to seek, receive and impart information and ideas of all kinds, regardless of frontiers, either orally, in writing or in print, in the form of art, or through any other media of his choice."

36. Article 19, UDHR ibid

37. "Freedom of Information" supra

38. supra

39. B. Applicability of international law, $\mathrm{A} / \mathrm{RES} / 37 / 92$. Principles governing the use by states of artificial earth satellites for international direct television broadcasting. https://www.un.org/documents/ga/res/37/a37r092. htm

40. J. Consultations and agreements between States, ibid.

41. Colliard supra

42. Ibid

43. Cherreau supra at 26

44. (1990) 12 EHRR 485

45. Secrecy of Telecommunications - (1) Members agree to tke all possible meures, compatible with the system of telecommunication used, with a view to ensreing the secrecy of international correspondence.

46. $\S 1$ (1) - The establishment and use of broadcasting stations (sound broadcasting and television broadcasting stations) on board ships, aircraft or any other floating or airborne objects outside national territories is prohibited.

47. Council of Europe, European Convention for the Protection of Human Rights and Fundamental Freedoms, as amended by Protocols Nos. 11 and 14, 4 November 1950, ETS 5, available at: https://www.refworld.org/docid/3ae6b3b04.html [accessed 17 July 2019, Time 23:49]

48. European Court of Human Rights, Allée des Droits de l'Homme, 67000 Strasbourg, France

49. Human Rights Case Digest 1990. [online] Available

at: https://heinonline.org/HOL/LandingPage?handle= hein.journals/hurcd $1 \& \operatorname{div}=51 \&$ id=\&page $=$

[Accessed 17 Jul. 2019, Time 16.35]

50. Medium. (2019). State Sovereignty and Human Rights - Irreconcilable Tensions. [online] Available at: https://medium.com/@hollybrooke/statesovereignty-and-human-rights-irreconcilabletensions-462d356ae063 [Accessed 18 Jul. 2019, Time 15:04].

51. Adopted by General Assembly resolution 41/128 of 4 December 1986
52. Reports on the International Dimensions of the Right to Development as a Human Right, E/CN.4/1334, December 1, 1978; Study on the Regional and National Dimensions of the Right to Development as a Human Right, E/CN/4/1421 and 1488, of April 13, 1980, and December 31, 1981.

53. A/RES/21/128, December 4, 1986, adopted by 146 against 1 (United States) and no assentation.

54. 54 A/RES/37/92. Principles Governing The Use By States Of Artificial Earth Satellites For International Direct Television Broadcasting

55. The text of Article 2(2) of "Declaration on the Right to Development" reads as follows: All human beings have a responsibility for development, individually and collectively, taking into account the need for full respect for their human rights and fundamental freedoms as well as their duties to the community, which alone can ensure the free and complete fulfilment of the human being, and they should therefore promote and protect an appropriate political, social and economic order for development.

56. Paragraph $\mathrm{C}(5)$ of $\mathrm{A} / \mathrm{RES} / 37 / 92$ reads as follows of : Rights and Benefits- Every State has an equal right to conduct activities in the field of international direct television broadcasting by satellite and to authorize such activities by persons and entities under its jurisdiction. All States and peoples are entitled to and should enjoy the benefits from such activities.

57. supra

58. Colliard Cl. A: "Les principes regissant la teledetection spatiale", AFDI, 1966, pp. 697-714

59. The text of Article I (2) reads as follows : All peoples may, for their own ends, freely dispose of their natural wealth and resources without prejudice to any obligations arising out of international economic co-operation, based upon the.

60. The text of Article I (2) reads as follows: The States Parties to the present Covenant undertake to guarantee that the rights enunciated in the present Covenant will be exercised without discrimination of any kind as to race, colour, sex, language, religion, political or other opinion, national or social origin, property, birth or other status.

61. International Covenant on Economic, Social and Cultural Rights, Adopted and opened for signature, ratification and accession by General Assembly resolution 2200A (XXI) of 16 December 1966 entry into force 3 January 1976, in accordance with article 27. 